\title{
Photoprotective Effects of Blue Light Absorbing Filter against LED Light Exposure on Human Retinal Pigment Epithelial Cells In Vitro
}

Eva Chamorro ${ }^{\star 1}$, Sergio F Carralero ${ }^{\star *}$, Cristina Bonnin-Arias ${ }^{1}$, María Jesús Pérez-Carrasco ${ }^{2}$, Javier Muñoz de Luna ${ }^{3}$, Daniel Vázquez Ing ${ }^{3}$ and Celia Sánchez-Ramos ${ }^{1,2}$

${ }^{1}$ Neuro-Computing and Neuro-Robotics Research Group, Universidad Complutense de Madrid, C/ Arcos de Jalón, 118. 28037. Madrid, Spain

${ }^{2}$ Optometry and Vision Department, Facultad de Óptica y Optometría, Universidad Complutense de Madrid, C/ Arcos de Jalón, 118. 28037. Madrid, Spain

${ }^{3}$ Optics Department, Facultad de Óptica y Optometría, Universidad Complutense de Madrid. C/Arcos de Jalón, 118. 28037. Madrid, Spain

\#These authors contributed equally to this work

\begin{abstract}
Background: Over the recent years, several researches have speculated about the effects of Light Emitting Diodes (LEDs) radiation on retinal epithelium cells (RPE). Worldwide, most people live exposed to LEDs irradiation incorporated in screens of PCs, phones and TV sets. These lights give rise to the formation of reactive oxygen species and induce mutagenic mechanisms which lead to apoptosis and consequently to degenerative eye diseases, such as age-related macular degeneration (AMD). Thus, it is a priority interest to develop appropriate solutions for the growing industry field of LED light phototoxicity. The aim of this study was to investigate the protective effects of blue light absorbing filters in order to decrease induced apoptosis on human retinal pigment epithelial cells.
\end{abstract}

Methods: Human retinal pigment epithelial cells were exposed to 3 light-darkness (12 hours/12 hours) cycles of white $\left(T^{\mathrm{a}} 5400^{\circ} \mathrm{K}\right)$, blue $(468 \mathrm{~nm})$, green $(525 \mathrm{~nm})$ and red $(616 \mathrm{~nm})$ LED light. Light irradiance was $5 \mathrm{~mW} / \mathrm{cm}^{2}$. Oxidative stress was evaluated by H2DCFDA staining, mitochondrial membrane potential by TMRM staining, DNA damage by $\mathrm{H} 2 \mathrm{AX}$ histone activation, apoptosis by caspase- 3 activation, and cell viability by DAPI.

Results: Our results have shown that the use of a blue light absorbing filter decreased cellular apoptosis by $56-89 \%$ and DNA damage by $57-81 \%$. A decrease in ROS level production and an increase in cellular viability was also obtained.

Conclusion: This study suggests that blue light absorbing filters may protect against LED lighting photo toxicity and, consequently, provides a photo protector effect.

Keywords: Retinal light toxicity; Apoptosis; Retinal degeneration; Epithelial defects; Free radicals

\section{Background}

Due to the relationship between visible-light exposure and increased risk of retinal degenerative diseases observed in humans, mainly AgeRelated Macular Degeneration (AMD), over the recent years, several researches have focused on retinal light-induced damage. Given the aging population, the socioeconomic impact of AMD is increasing and, consequently, therapeutic strategies to delay the progression of the pathology are a concern of interest [1].

The idea that light contributes to retinal cell damage arose several years ago. Since then, light damage has been classified into two classes according to the wavelengths of light that gives rise to the greatest level of damage. Noell was the first to determine that the action spectrum of phototoxicity was similar to the action spectrum of rhodopsin, thus it was described as a photochemical damage caused by long exposures to low irradiances which first manifestations are seen in the photoreceptors [2]. Later, Ham described a light damage caused by higher irradiances and shorter exposures than those described by Noell; Ham's damage was explained as a retinal phototoxicity that peaks around $425 \mathrm{~nm}$, and which is initiated in the RPE $[3,4]$.

The human retina is exposed to a high number of artificial lights of different spectra and intensities. Light-emitting diodes (LEDs) are novel light sources that reduce the negative effects of conventional bulbs, regarding to energy use, lifetime and temperature. In the coming years, LEDs will progressively replace incandescent or fluorescent lamps. It is estimated that as of September $1^{\text {st }} 2016$ there will be no incandescent lights in Europe [5]. However, recent studies have speculated that LED light radiation may cause ocular damage (apoptosis and other cell changes) as LEDs present specific spectral composition and energetic characteristics [5-8].

On the other hand, several studies have demonstrated that ocular photo-oxidative processes can be reduced by the use of lenses with appropriate transmission properties that filter shorter wavelength of the visible spectrum [9-12]. Thus, the purpose of our study was to evaluate the protective effects of a blue light absorbing filter on RPE cells exposed to LED light, focusing on oxidative stress, mitochondrial membrane potential, DNA damage, apoptosis and cell viability.

\section{Methods}

\section{Cell culture of human RPE}

A human RPE cell line HRPEpiC (ScienceCell Research Laboratories, USA) was used in the study. Cell cultures were grown

*Corresponding author: Eva Chamorro, Facultad de Óptica, Optometría y Visión Universidad Complutense de Madrid. C/ Arcos de Jalón, 118. 28037. Madrid, Spain, Tel: +34 650753091; E-mail: eva.chamorro@opt.ucm.es

Received September 15, 2013; Accepted December 12, 2013; Published December 18, 2013

Citation: Chamorro E, Carralero SF, Bonnin-Arias C, Pérez-Carrasco MJ, de Luna JM, et al. (2013) Photoprotective Effects of Blue Light Absorbing Filter against LED Light Exposure on Human Retinal Pigment Epithelial Cells In Vitro. J Carcinog Mutagen S6: 008. doi:10.4172/2157-2518.S6-008

Copyright: (c) 2013 Chamorro E, et al. This is an open-access article distributed under the terms of the Creative Commons Attribution License, which permits unrestricted use, distribution, and reproduction in any medium, provided the original author and source are credited. 
Citation: Chamorro E, Carralero SF, Bonnin-Arias C, Pérez-Carrasco MJ, de Luna JM, et al. (2013) Photoprotective Effects of Blue Light Absorbing Filter against LED Light Exposure on Human Retinal Pigment Epithelial Cells In Vitro. J Carcinog Mutagen S6: 008. doi:10.4172/2157-2518. S6-008

in a low-serum epithelial cell culture medium (ScienceCell Research Laboratories, USA). Once confluent, the cells were removed from the culture dish with Trypsin/EDTA solution (Sigma-Aldrich, USA). Cells were plated in a 96 well, black clear Imaging Plate (Becton, Dickinson and Company, USA) with Poly-L-Lysine (Sigma-Aldrich, USA) Coating (density $=5000$ cells/well). The cells were incubated in a humidified atmosphere of $5 \% \mathrm{CO}_{2}$ and $95 \%$ air at $37^{\circ} \mathrm{C}$, and the culture medium was changed every $24 \mathrm{~h}$, following each light phase.

\section{Light exposure}

The culture medium was exposed to white light ( $\left.\mathrm{T}^{\mathrm{a}} 5400^{\circ} \mathrm{K}\right)$, blue light $(468 \mathrm{~nm})$, green light $(525 \mathrm{~nm})$ or red light $(616 \mathrm{~nm})$, in well chambers at an intensity of $5 \mathrm{~mW} / \mathrm{cm}^{2}$. The light was delivered from a LED-based system for 3 light-darkness (12 hours/12 hours) cycles. The exposition conditions were determined in previous studies; based on the results obtained, we selected 3 cycles of light/darkness as the irradiation provided is enough to produce damage in the RPE cells. On the other hand, we selected a circadian cycle with a darkness phase in order to allow a cell-recovery period in which cells can regenerate partially. Cells were taken for experimentation after the last dark phase $(12 \mathrm{~h})$ of the total exposure cycle; thus measures of phototoxicity were done after 12 hours of darkness, under two situations: (1) RPE cells exposed to light without a blue absorbing lens and (2) RPE cells exposed to light with a blue light filtering lens attached under the surface of the culture well and centered over the light beam. Control groups consisted of RPE cells kept in darkness. Figure 1 shows a schematic diagram of the LED light irradiation system, its spectral irradiance and the spectral transmission of the blue light filtering lenses. Table 1 shows the irradiance level $\left(\mathrm{mW} / \mathrm{cm}^{2}\right)$ of LED light on RPE cells with/without protection with a blue light absorbing filter.

\section{Intracellular ROS production}

Light-treated and untreated HRPEpiC cells were washed with phosphate-buffered saline, (PBS, Sigma-Aldrich, USA). Then, diluted (1:1000 5-(and-6)chloromethyl-2',7'-dichlorodihydrofluorescein diactate acetyl ester (H2DCFDA, Invitrogen, Germany) was added to the culture medium and incubated at $37^{\circ} \mathrm{C}$ for 30 minutes. In the presence of ROS, this probe was oxidazed to the highly fluorescent dichlorofluorescein compound (DCF). The fluorescence intensity of the intracellular tapped DCF indicates the amount of intracellular ROS. The average of cellular fluorescence intensity was measured using BD Pathway 855 Bioimager (Becton, Dickinson and Company, USA). Cells were imaged at 492-495 $\mathrm{nm}$ (excitation band pass filter) and 517-527 $\mathrm{nm}$ (emission cutoff filter) and images were analyzed using Attovision Software (Becton, Dickinson and Company, USA).

\section{Mitochondrial membrane potential (MMA)}

After treatment, cells were stained with Tetramethylrhodamine,

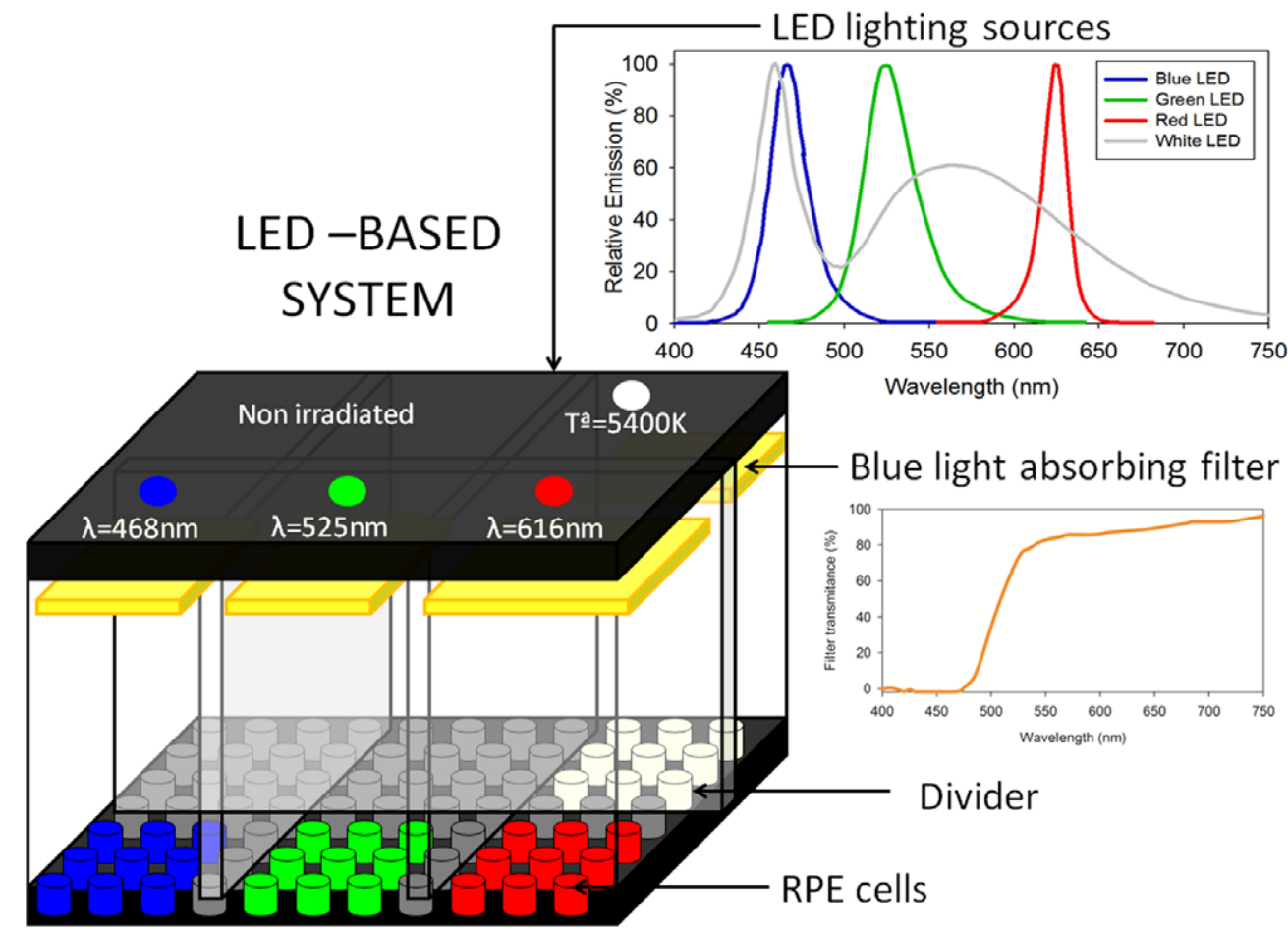

Figure 1: Schematic diagram of the main components of the LED-based system. Spectral irradiance of the different LED lighting sources: white (Ta5400 $\left.{ }^{\circ} \mathrm{K}\right)$, blue $(468 \mathrm{~nm})$, green $(525 \mathrm{~nm})$ and red $(618 \mathrm{~nm})$ and transmittance of the blue light absorbing filter.

\begin{tabular}{|c|c|c|}
\hline & No filter & Filter \\
\hline White & 4.68 & 3.64 \\
\hline Blue $(468 \mathrm{~nm})$ & 5.11 & 1.15 \\
\hline Green $(525 \mathrm{~nm})$ & 4.54 & 3.94 \\
\hline $\operatorname{Red}(618 \mathrm{~nm})$ & 5.00 & 4.67 \\
\hline
\end{tabular}

Table 1: Irradiance level $\left(\mathrm{mW} / \mathrm{cm}^{2}\right)$ of LED light on protected and non-protected RPE cells with a blue light absorbing filter. 
Citation: Chamorro E, Carralero SF, Bonnin-Arias C, Pérez-Carrasco MJ, de Luna JM, et al. (2013) Photoprotective Effects of Blue Light Absorbing Filter against LED Light Exposure on Human Retinal Pigment Epithelial Cells In Vitro. J Carcinog Mutagen S6: 008. doi:10.4172/2157-2518. S6-008

A)

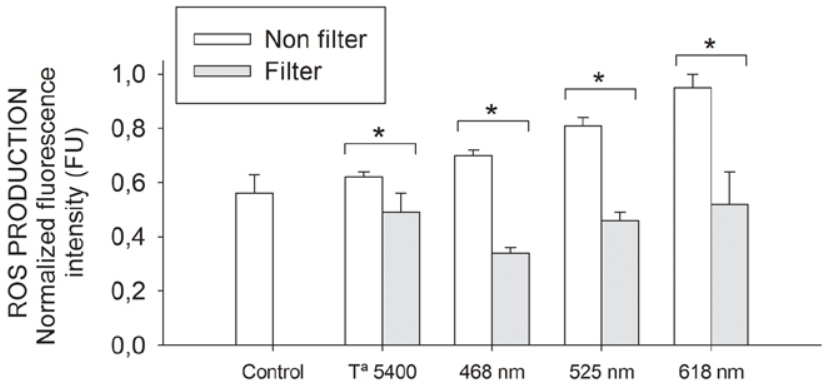

B)

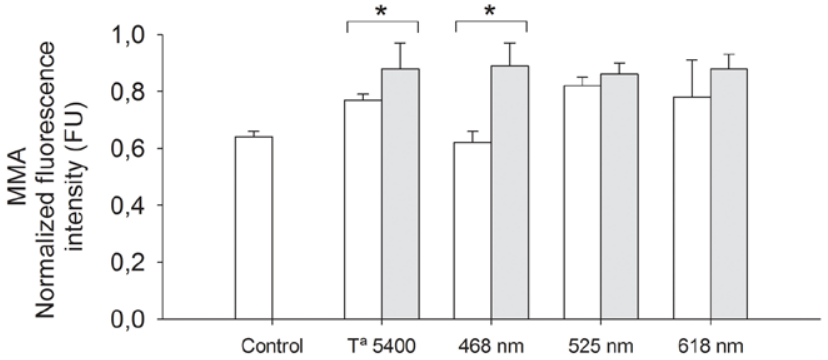

C)

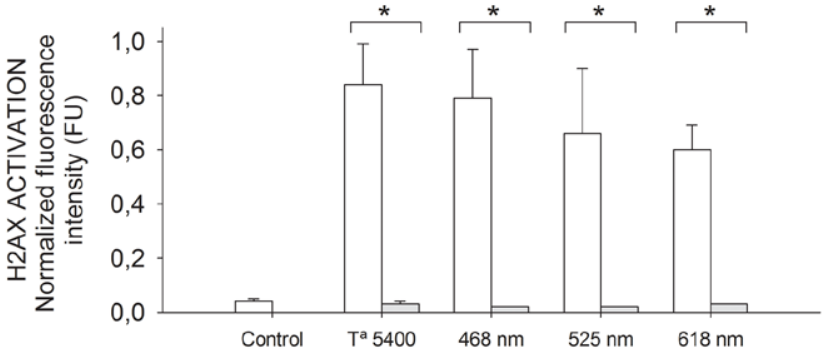

D)

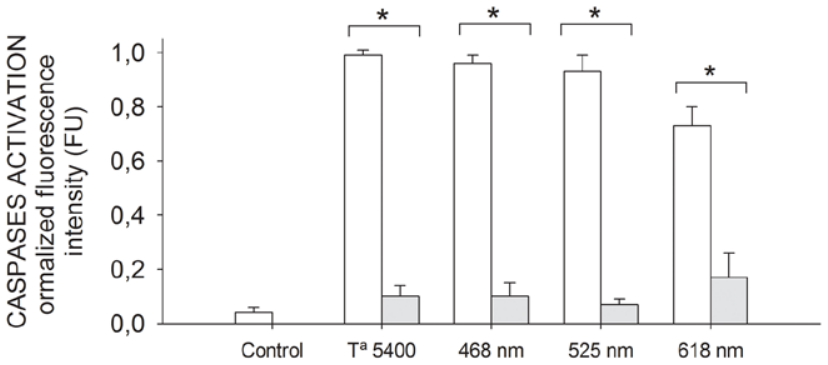

E)

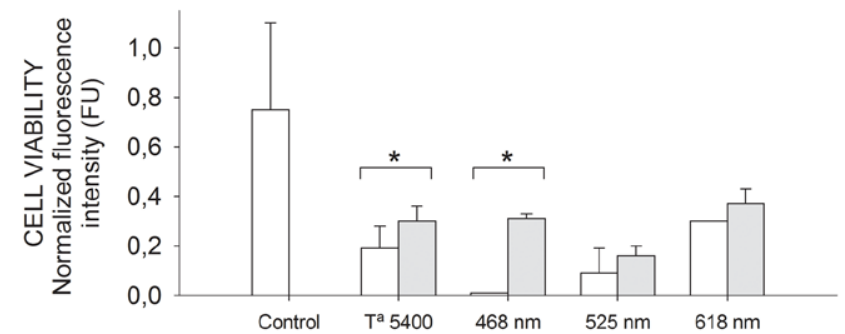

Figure 2: Photoprotective effects of blue light absorbing filter on human RPE cells in vitro. HRPEpiC cells were exposed to white (Ta5400 ${ }^{\circ} \mathrm{K}$ ), blue (468 nm), green $(525 \mathrm{~nm})$ and red $(616 \mathrm{~nm})$ LED lighting (irradiated cells) in the presence or not of a blue light absorbing filter for 3 light-darkness cycles (12 hours/12 hours). Control groups consisted of RPE cells kept in darkness. The graph displays mean normalized fluorescence intensity radios of protected cells versus non protected cells. Bars represent mean + SD from $n=3-5$ experiments. (A) ROS production determined by the H2DCFDA staining. (B) Mitochondrial membrane potential determined by the TMRM staining. (C) DNA damage determined by the activation of H2AX histone. (D) Apoptosis determined by the activation of caspase-3. (E) Cellular viability of HRPEpic cells determined by labeling all nuclei with DAPI. ${ }^{*} p<0.05$, t-student test. 
Citation: Chamorro E, Carralero SF, Bonnin-Arias C, Pérez-Carrasco MJ, de Luna JM, et al. (2013) Photoprotective Effects of Blue Light Absorbing Filter against LED Light Exposure on Human Retinal Pigment Epithelial Cells In Vitro. J Carcinog Mutagen S6: 008. doi:10.4172/2157-2518. S6-008

methyl ester, TMRM probe (Invitrogen, Germany), a red-orange fluorescent dye that is readily sequestered by active mitochondria. Briefly, cells were incubated with $50 \mu \mathrm{M}$ TMRM solution for 30 minutes at $37^{\circ} \mathrm{C}$. Fluorescence intensity was imaged using BD Pathway 855 Bioimager (Becton, Dickinson and Company, USA) and an excitation band pass filter at $549 \mathrm{~nm}$ and an emission cutoff filter at $572 \mathrm{~nm}$.

\section{Caspase 3 activation assay}

Caspase 3 activation was assessed by Immunocytochemistry using a caspase 3 antibody (Cell Signaling Technology, USA) that detects endogenous levels of the large fragment $(17 / 19 \mathrm{kDa})$ of activated caspase- 3 resulting from cleavage adjacent to Asp175. This antibody does not recognize full length caspase- 3 or other cleaved caspases. After light exposure, the cells were washed with PBS and fixed in $4 \%$ paraformaldehyde (Sigma-Aldrich, USA) for 1 hour. After the fixation step cells, were washed three times with PBS and permeabilized with 0.3\% Triton X100-PBS (Sigma-Aldrich, USA) for 10 minutes, followed by three washing steps. The samples were then blocked with $3 \%$ Bovine Serum Albumin (BSA, Sigma-Aldrich, USA) in PBS for 30 minutes and finally anti-Caspase 3 antibody was added at $1 / 350$ in PBS- $0.5 \%$ BSA solution and then cells were incubated for 60 minutes at room temperature. After three washing steps, the secondary antibody Alexa 633 was added at 1/400 in PBS-0.5\% BSA solution and then samples were incubated for 60 minutes at room temperature. After three washing steps, the fluorescence of the samples was measured in the Pathway 855 automated fluorescence microscope using an excitation band pass filter at $632 \mathrm{~nm}$ and an emission cutoff filter at $647 \mathrm{~nm}$. Caspase 3 is primarily located in the cytoplasm and the algorithm for the image analysis was set to sample an area around the nucleus previously stained with DAPI.

\section{Phosphorilated H2AX detection}

After treatment, cells were fixed for 60 minutes with pre-warmed formaldheyde, $4 \%$ in PBS, washed with PBS and permeabilized with
0.3\% Triton X100-PBS for 10 minutes. Cells were washed twice with PBS and blocked using 3\% BSA (in PBS) for 30 minutes. For detection of Anti-gamma H2A.X (phospho S139), an antibody (Abcam, UK) at $3 \mathrm{ug} / \mathrm{ml}$ in $0.5 \%$ BSA was used. After $1 \mathrm{~h}$ at room temperature, the primary antibody was removed. Three washed prepared the cells for the addition of the Alexa Fluor 633 conjugated secondary antibody.

\section{Cell viability}

The DNA dye nuclear stain 4'6-diamidine-2-phenylindole dihydrochloride (DAPI, Sigma-Aldrich, USA), was added at this point and removed with the secondary antibody after a 1 hour incubation period. Cells were washed and then plates were imaged on the BD 855 Pathway Bioimager. Analysis of the image data was then performed, using Attovision software (Becton, Dickinson and Company, USA).

\section{Statistical analysis}

Each experiment was repeated three times. The values were given as mean \pm SD. Data was analyzed using an unpaired two-tailed t-test by Statgraphics version Centurion XVI.I (USA). A p value less than 0.05 was considered statistically significant.

\section{Results}

\section{Measurement of intracellular ROS production}

After 3 light-darkness (12 hours/12 hours) cycles exposure to LED light, ROS production levels increased in the absence of a blue light filter in comparison with non-irradiated cells. However, we found a lower level of reactive oxygen species production in RPE cells protected by a blue light filter. With the blue light filter, differences in ROS production levels were significantly lower than those without the filter for the four light sources: white $\left(\mathrm{T}^{\mathrm{a}} 5400^{\circ} \mathrm{K}\right)$, blue $(468 \mathrm{~nm})$, green $(525 \mathrm{~nm})$ and red $(616 \mathrm{~nm})$ LED light (Figure 2A).
A)

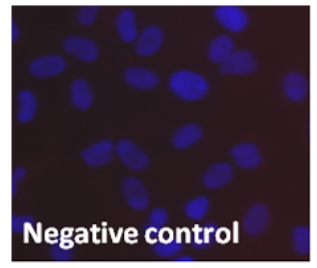

B)

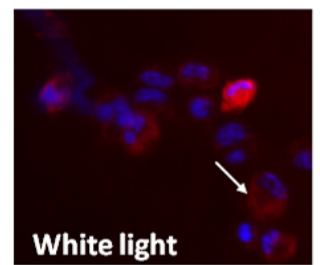

C)

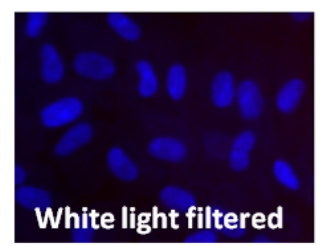

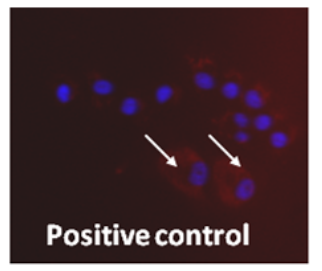
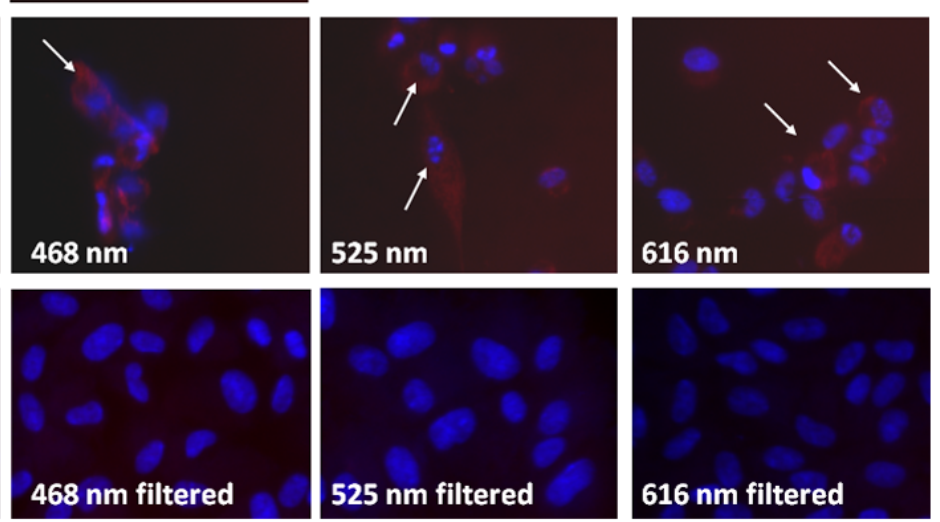

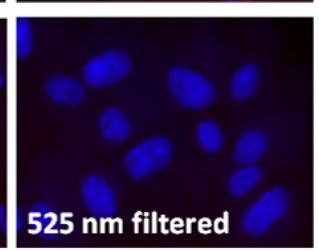

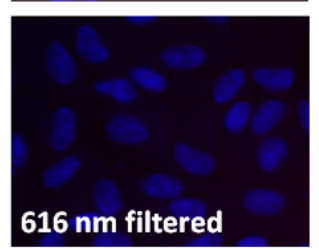

Figure 3: Apoptosis in HRPEpiC cells exposed to white $\left(\mathrm{T}^{2} 5400^{\circ} \mathrm{K}\right)$, blue (468 nm), green $(525 \mathrm{~nm})$, and red (618 $\left.\mathrm{nm}\right)$ LED lighting (irradiated cells) for 3 lightdarkness cycles (12 hours/12 hours). Apoptosis determined by the activation of caspase- 3 is observed as a pink coloration around DAPI-stained cells. The white arrows indicate apoptotic cells. (A) Representative images of RPE cells maintained in darkness (negative control) and RPE cells treated with $\mathrm{H}_{2} \mathrm{O}_{2}$ to provocate toxicity (positive control); (B) Effects of LED lighting on human RPE cells in vitro without filter; (C) Photoprotective effects of blue light absorbing filter on human RPE cells. 
Citation: Chamorro E, Carralero SF, Bonnin-Arias C, Pérez-Carrasco MJ, de Luna JM, et al. (2013) Photoprotective Effects of Blue Light Absorbing Filter against LED Light Exposure on Human Retinal Pigment Epithelial Cells In Vitro. J Carcinog Mutagen S6: 008. doi:10.4172/2157-2518. S6-008

\section{Measurement of mitochondrial membrane potential}

After 3 light-darkness cycles of irradiation, no significant effect on mitochondrial membrane potential was detectable compared to control cells (non-irradiated) for any of the different LED lights. Nevertheless, cells exposed to blue $(468 \mathrm{~nm})$ and white ( $\left.\mathrm{T}^{\mathrm{a}} 5400^{\circ} \mathrm{K}\right)$ light have shown a significant increase in mitochondrial membrane potential when cells were protected with a blue light absorbing filter (Figure 2B).

\section{Effects of light on DNA damage of RPE}

Significant H2AX activation was observed on not protected RPE cells exposed to LED light, suggesting DNA damage. The fluorescence microscopic data for all irradiated RPE cells show an increased degradation of nucleic acids in comparison with the control cells. However, RPE cells protected with a blue light absorbing filter, normal values of $\mathrm{H} 2 \mathrm{AX}$ were found for the four light sources. The inhibitory effects of the blue light absorbing filter on $\mathrm{H} 2 \mathrm{AX}$ activation was $81 \%$ for white $\left(\mathrm{T}^{\mathrm{a}} 5400^{\circ} \mathrm{K}\right) \mathrm{LED}$ light, $77 \%$ for blue $(468 \mathrm{~nm}), 64 \%$ for green $(525 \mathrm{~nm}), 57 \%$ for red $(616 \mathrm{~nm})$ monochromatic LED light (Figure 2C).

\section{Detection of apoptosis}

Apoptosis determined by the activation of caspases- 3 is observed as a pink coloration around DAPI-stained cells. In Figure 3, representative images of RPE cells protected and not protected with a blue light absorbing filter are shown. Fluorescence microscopy shows that the percentage of apoptotic cells was reduced on light exposed RPE cells protected with a blue light absorbing filter in comparison with not protected RPE cells. Cell death reduction due to the filter effects was $89 \%, 86 \%, 86 \%$ and $56 \%$ for white $\left(\mathrm{T}^{\mathrm{a}} 5400^{\circ} \mathrm{K}\right)$, blue $(468 \mathrm{~nm})$, green $(525 \mathrm{~nm})$ and red $(616 \mathrm{~nm})$ LED light irradiated RPE, respectively (Figure 2D)

\section{Cell viability}

Under DAPI staining, it was observed that illuminated RPE cells became nonviable. The difference in the cell number of non-protected RPE cells irradiated by LED light and RPE cells protected with a blue light absorbing filter was statistically significant for blue $(468 \mathrm{~nm})$ and white $\left(\mathrm{T}^{\mathrm{a}} 5400^{\circ} \mathrm{K}\right)$ LED light $(\mathrm{p}<0.01)$. Maximum damage reduction was observed in cells exposed to blue LED light. In the experiments $99 \%$ and $81 \%$ of not protected irradiated cells became nonviable after exposure to blue $(468 \mathrm{~nm})$ or white $\left(\mathrm{T}^{\mathrm{a}} 5400^{\circ} \mathrm{K}\right)$ light. The filter inhibits light mediated cell death by $30 \%$ for blue ( $468 \mathrm{~nm}$ ) light and by $11 \%$ for white $\left(\mathrm{T}^{\mathrm{a}} 5400^{\circ} \mathrm{K}\right)$ light. Blue light absorbing filter caused a slight decrease in the number of nonviable RPE cells irradiated with green $(525 \mathrm{~nm})$ and red $(618 \mathrm{~nm})$ light; however the difference was not statistically significant (Figures 2E).

\section{Discussion}

Recent studies have speculated that LED light radiation may cause ocular damage, mainly oxidative stress, which leads to apoptosis [58]. However, the potential protective effects of blue light absorbing filter against phototoxicity caused by these new light sources have not been explored. The present study shows that absorbing filters in the blue region of the spectrum may protect RPE cells from the damaging effects of LED light. The results of this study clearly show that a blue light absorbing filter decreases the apoptotic cellular death by $50-89 \%$ and inhibits DNA damage by $57-81 \%$, decreases ROS production and increases mitochondrial membrane potential.

The results obtained in our study provide preliminary data that may be clinically relevant in retinal pathologies progress. Some epidemiological studies have demonstrated an association between visible-light exposure and an increased risk in age-related macular degeneration (AMD) progression [9,13-16]. Age-related macular degeneration (AMD) is the leading cause of legal blindness in the population over 60 years in developed countries [17-21]. It is known that the RPE cells play an important role in the development and progression of this pathology. In AMD, the photochemical reaction and oxidative stress induced by light may be the main responsible in the degeneration of RPE cells [16,20,22-25]. The exposure to blue light induces the production of ROS in the mitochondria of RPE cells and leads to an increase in DNA changes, which subsequently result in apoptosis [20,26-29]. The RPE cell induced dysfunction is considered as a prelude to the photoreceptor cell degeneration that characterizes the visual impairment associated with AMD [30,31]. The reduction in phototoxic damage provided by this blue light absorbing filter may be implemented in eyeglasses and contact lenses to protect the retina of the phototoxic effects.

Our results demonstrate an experimental evidence for the damage of white $\left(\mathrm{T}^{\mathrm{a}} 5400^{\circ} \mathrm{K}\right)$ light to RPE cells and the protective effect of a blue light absorbing filter, after 3 light-darkness (12 hours/12 hours) cycles. In cells exposed to white ( $\left.\mathrm{T}^{\mathrm{a}} 5400^{\circ} \mathrm{K}\right) \mathrm{LED}$ light, the filter provides a reduction in light transmission of $22 \%$, that resulted in an $89 \%$ decline in apoptotic cells, an $81 \%$ reduction in DNA damage and an $11 \%$ increase in cell viability. It is relevant to keep in mind that every day the human visual system is exposed to different types of lights, including sunlight and artificial lights. Taking into account blinking time and 8 hours per day of sleep time, the human eye is exposed to 5000 hours of irradiation per year. On the other hand, according to previous measures carry out by the Neuro-Computing and Neuro-Robotics Research Group, general white light contains a $24 \%$ of short wavelengths, between 400 and 500 $\mathrm{nm}$. In a society exposed to high amount of phototoxic radiations it seem obvious that eye protection against such types of light is necessary.

Despite transmittance differences of the blue light absorbing filter used in different experiments, our results are consistent with previous reports that a blue light absorbing filter incorporated in an intraocular lens attenuates light-induced damage. Sparrow et al. suggested that a partial blue light absorbing filter produces approximately $80 \%, 82 \%$ and $78 \%$ decrease in the death of A2E-laden RPE exposed to blue $(430 \mathrm{~nm})$, green $(550 \mathrm{~nm})$ and white $\left(\mathrm{T}^{\mathrm{a}} 5400^{\circ} \mathrm{K}\right)$ light [30]. However, Hui et al. demonstrated that partial blue light absorbing filter protects against RPE damage, increasing cell viability to $79.5 \%$ in the nonirradiated control, growing free glutathione (GSH) levels and pigment epithelium-derived factor (PEDF) and, decreasing ROS and vascular endothelial grown factor (VEGF) levels in A2E-laden RPE cells [31] Also, Yanagi et al. found that VEGF production induced by white light exposure was inhibited with a partial blue light absorbing filter in A2Eladen RPE cells and described as an inhibitory effect of light-induced cell damage with the partial blue light absorbing filter. As a result cell survival enhanced up to $42 \%$ in the non-irradiated control [17].

The research carried out by Zhou et al. is relevant to our case. Zhou et al. tested the in vitro response of RPE cells exposed to blue light and protected by polycarbonate filters. These filters contain different levels of a blue light absorbing pigment. Cells were irradiated with 430 $\pm 20 \mathrm{~nm}$ light at an output power of $8 \mathrm{~mW} / \mathrm{cm}^{2}$ or $1 \mathrm{~mW} / \mathrm{cm}^{2}$ for 24 hours. The data showed a significantly reduction in cell viability (40\%). Moreover, the range of protection was dependent on the transmittance of the filter. Blue light absorbing filter induced an $18-47 \%$ reduction in cell death and a $23-50 \%$ increase in percent of viable cells, according to the absorption of the filter [9]. 
Citation: Chamorro E, Carralero SF, Bonnin-Arias C, Pérez-Carrasco MJ, de Luna JM, et al. (2013) Photoprotective Effects of Blue Light Absorbing Filter against LED Light Exposure on Human Retinal Pigment Epithelial Cells In Vitro. J Carcinog Mutagen S6: 008. doi:10.4172/2157-2518. S6-008

It is important to note that previous studies have supplemented the medium with fluorophore A2-E, so RPE cells have A2E accumulation. It has been shown that the accumulation of A2E by cultured RPE confers sensitivity to light-induced damage. Specifically, the short wavelength visible spectrum was found to induce apoptosis of A2E-laden RPE cells [32].

Following Rezai et al. and Kernt et al. [20,33], our study experiments were performed with human RPE cells which did not contain lipofuscin fluorophore A2E accumulation. Our results indicate that, even in the absence of lipofuscin LED light may be toxic and that blue light absorbing lens protects RPE cells from blue light-induced apoptosis. The recent study of Rezai et al. found that partial blue light absorbing filter reduced approximately $49 \%$ of RPE cell apoptosis [20]. On the other hand, Kernt et al. showed that the reduction in RPE cell death was accompanied by a significant decrease of the antiapoptotic protein Bcl-2 and increase in Bax and VEGF-A. Thus, supporting the theory that a partial blue light absorbing filter can help to prevent apoptosis in the human RPE exposed to light [33].

We suggest that light with varying intensity and exposure times may have different effects on RPE cells. Apoptosis induced by light is preceded by several events; it is reasonable to consider that illumination initially caused sublethal cellular stress, including a decline of mitochondrial activity, and continued illumination for a longer period induced lethal stress causing cell apoptosis [17]. H2AX activation and Caspases activation were the variables that showed a greater protective effect induced by the blue light absorbing filter. However, no differences were found in mitochondrial membrane potential. This may be due to the characteristics of the light exposure. We used a high light intensity of $5 \mathrm{~mW} / \mathrm{cm}^{2}$ produced by a LED-based system for 3 light-darkness cycles (12 hours/12 hours) with white light ( $\left.\mathrm{T}^{\mathrm{a}} 5400^{\circ} \mathrm{K}\right)$, blue light $(468 \mathrm{~nm})$, green light $(525 \mathrm{~nm})$ or red light $(616 \mathrm{~nm})$ in well chambers that induced lethal stress. This value can be observedin everyday life situations. So, we have selected this value in order to match with similar studies on this subject [30,31]. This light intensity implies 34.150 lux for an incandescent light source or 33.446 lux for a D65 (skylight) light source. It is alike to the horizontal irradiance for a person looking up to a clear sky day when the sun is around $37.5^{\circ} \mathrm{C}$ [34] or a person at $20 \mathrm{~cm}$ of a $100 \mathrm{w}$ incandescent lamp [35]. Regarding our results, it is necessary to clarify the fact that the blue-light filter decreased the toxic effects of all types of lights used. As it is shown in Figure 1, the filter mainly absorbs the short wavelength. However, it also partially absorbs a smaller percentage of the rest of wavelengths, including long wavelengths. Also, due to the interposition of an element in the light path, there is a decrease in light intensity. This explains why a decrease of damage was found in cells exposed to the long wavelength when protected by a blue light absorbing filter.

Regarding ROS production results, a high level of ROS production could be expected in RPE cells exposed to short wavelength (blue or white light) in comparison to cells exposed longer wavelength (green or red light). However our results show a higher level of ROS production in cells exposed to red and green light than in cells exposed to white and blue light. This is explained by the level of apoptosis. In cells exposed to blue and white light, we observed a high level of apoptosis, thus a low level of surviving cells which can produce ROS. However in cells exposed to red and green light the apoptosis is lower, and so there are more cells that can produce ROS, showing a higher level in this value. However, bearing in mind that the existence of photosensitizes such as riboflavin in the culture medium can affect light-dependent ROS generation [36-38], our results on ROS production must be taken cautiously.

Considering that the results seem to play a very important role in the applied biology in this specific field of the human health, we also have done studies to demonstrate the effects of light in human retina in vivo, in order to demonstrate also in vivo the results obtained using only cellular cultures. These results are part of a $\mathrm{PhD}$ and the results are in consideration for another manuscript.

In conclusion, this study has found that the use of a blue light absorbing filter reduces phototoxic damage in human RPE cells exposed to LED light, providing an ocular photoprotector effect. After 3 light-darkness cycles (12 hours/12 hours) exposure to LED light, RPE cells protected by a blue light absorbing filter showed a decrease in apoptotic death accompanied by a decrease in DNA damage and a reduction in ROS levels. Future investigation are necessary in order to develop appropriate solutions for the growing industry field of LEDlight phototoxicity.

\section{Acknowledgement}

This work has been supported in part by Fundación Mapfre (Spain). This work has been supported in part by Fundación Mapfre (Spain).

\section{References}

1. Rozanowska MB (2012) Light-induced damage to the retina: current understanding of the mechanisms and unresolved questions: a symposium-inprint. Photochem Photobiol 88: 1303-1308.

2. Noell WK (1980) Possible mechanisms of photoreceptor damage by light in mammalian eyes. Vision Res 20: 1163-1171.

3. Ham WT Jr, Mueller HA, Ruffolo JJ Jr, Clarke AM (1979) Sensitivity of the retina to radiation damage as a function of wavelength. Photochem Photobiol 29 735-743.

4. Ham WT Jr, Mueller HA, Sliney DH (1976) Retinal sensitivity to damage from short wavelength light. Nature 260: 153-155.

5. Behar-Cohen F, Martinsons C, Viénot F, Zissis G, Barlier-Salsi A, et al. (2011) Light-emitting diodes (LED) for domestic lighting: any risks for the eye? Prog Retin Eye Res 30: 239-257.

6. Chamorro E, Bonnin-Arias C, Pérez-Carrasco MJ, Muñoz de Luna J, Vázquez D, et al. (2013) Effects of light-emitting diode radiations on human retina pigment epithelial cells in vitro. Photochem Photobiol 89: 468-473.

7. Roehlecke C, Schaller A, Knels L, Funk RH (2009) The influence of sublethal blue light exposure on human RPE cells. Mol Vis 15: 1929-1938.

8. Zak PP, Ostrovsky MA (2012) Potential danger of Ligh Emitting Diode Illumination to the eye, in children and teenagers. Light Eng 20: 5-8.

9. Zhou J, Sparrow JR (2011) Light filtering in a retinal pigment epithelial cell culture model. Optom Vis Sci 88: 759-765.

10. Sparrow JR (2003) Therapy for macular degeneration: insights from acne. Proc Natl Acad Sci U S A 100: 4353-4354.

11. Rattner A, Nathans J (2006) Macular degeneration: recent advances and therapeutic opportunities. Nat Rev Neurosci 7: 860-872.

12. Sparrow JR, Parish CA, Hashimoto M, Nakanishi K (1999) A2E, a lipofuscin fluorophore, in human retinal pigmented epithelial cells in culture. Invest Ophthalmol Vis Sci 40: 2988-2995.

13. Age-Related Eye Disease Study Research Group (2000) Risk factor associated with age-related macular degeneration. A case-control study in the age-related eye disease study: Age-Related Eye Disease Study Report Number 3. Ophthalmology 107: 2224-2232.

14. Tomany SC, Cruickshanks KJ, Klein R, Klein BE, Knudtson MD (2004) Sunligh and the 10-year incidence of age-related maculopathy: the Beaver Dam Eye Study. Arch Ophthalmol 122: 750-757.

15. Cruickshanks KJ, Klein R, Klein BE (1993) Sunlight and age-related macula degeneration. The Beaver Dam Eye Study. Arch Ophthalmol 111: 514-518. 
Citation: Chamorro E, Carralero SF, Bonnin-Arias C, Pérez-Carrasco MJ, de Luna JM, et al. (2013) Photoprotective Effects of Blue Light Absorbing Filter against LED Light Exposure on Human Retinal Pigment Epithelial Cells In Vitro. J Carcinog Mutagen S6: 008. doi:10.4172/2157-2518. S6-008

16. Cruickshanks KJ, Klein R, Klein BE, Nondahl DM (2001) Sunlight and the 5 -year incidence of early age-related maculopathy: the beaver dam eye study. Arch Ophthalmol: 246-250.

17. Yanagi $Y$, Inoue $Y$, Iriyama A, Jang WD (2006) Effects of yellow intraocula lenses on light-induced upregulation of vascular endothelial growth factor. $\mathrm{J}$ Cataract Refract Surg 32: 1540-1544.

18. Ferris FL 3rd, Fine SL, Hyman L (1984) Age-related macular degeneration and blindness due to neovascular maculopathy. Arch Ophthalmol 102: 1640-1642.

19. Resnikoff S, Pascolini D, Etya'ale D, Kocur I, Pararajasegaram R, et al. (2004) Global data on visual impairment in the year 2002. Bull World Health Organ 82: 844-851.

20. Rezai KA, Gasyna E, Seagle BL, Norris JR Jr, Rezaei KA (2008) AcrySof Natural filter decreases blue light-induced apoptosis in human retinal pigment epithelium. Graefes Arch Clin Exp Ophthalmol 246: 671-676.

21. Klein R, Klein BE, Linton KL (1992) Prevalence of age-related maculopathy. The Beaver Dam Eye Study. Ophthalmology 99: 933-943.

22. Smith BT, Belani S, Ho AC (2005) Light energy, cataract surgery, and progression of age-related macular degeneration. Curr Opin Ophthalmol 16: 166-169.

23. Mainster MA (1987) Light and macular degeneration: a biophysical and clinical perspective. Eye (Lond) 1: 304-310.

24. Wang RJ (1975) Lethal effect of "daylight" fluorescent light on human cells in tissue-culture medium. Photochem Photobiol 21: 373-375.

25. Wu J, Seregard S, Spångberg B, Oskarsson M, Chen $E$ (1999) Blue light induced apoptosis in rat retina. Eye (Lond) 13: 577-583.

26. King A, Gottlieb E, Brooks DG, Murphy MP, Dunaief JL (2004) Mitochondriaderived reactive oxygen species mediate blue light-induced death of retinal pigment epithelial cells. Photochem Photobiol 79: 470-475.

27. Godley BF, Shamsi FA, Liang FQ, Jarrett SG, Davies S, et al. (2005) Blue light induces mitochondrial DNA damage and free radical production in epithelia cells. J Biol Chem 280: 21061-21066.
28. Ninnemann H (1974) Photoinhibition of isolated complexes I, II, and 3 of beef heart mitochondria. FEBS Lett 39: 353-358.

29. Ninnemann H, Butler WL, Epel BL (1970) Inhibition of respiration and destruction of cytochrome A3 by light in mitochondria and cytochrome oxidase from beef heart. Biochim Biophys Acta 205: 507-512.

30. Sparrow JR, Miller AS, Zhou J (2004) Blue light-absorbing intraocular lens and retinal pigment epithelium protection in vitro. J Cataract Refract Surg 30: 873878.

31. Hui S, Yi L, Fengling QL (2009) Effects of light exposure and use of intraocular lens on retinal pigment epithelial cells in vitro. Photochem Photobiol 85: 966969 .

32. Ben-Shabat S, Itagaki Y, Jockusch S, Sparrow JR, Turro NJ, et al. (2002) Formation of a nonaoxirane from A2E, a lipofuscin fluorophore related to macular degeneration, and evidence of singlet oxygen involvement. Angew Chem Int Ed Engl 41: 814-817.

33. Kernt M, Neubauer AS, Liegl R, Eibl KH, Alge CS, et al. (2009) Cytoprotective effects of a blue light-filtering intraocular lens on human retinal pigment epithelium by reducing phototoxic effects on vascular endothelial growth factoralpha, Bax, and Bcl-2 expression. J Cataract Refract Surg: 354-362.

34. Vazquez D, Bernabeu E (1997) Quantitative estimation of clear sky light in Madrid. Energy Build: 331-336.

35. OSRAM (2005) General Light Brochure. Spain: OSRAM.

36. Grzelak A, Rychlik B, Bartosz G (2001) Light-dependent generation of reactive oxygen species in cell culture media. Free Radic Biol Med 30: 1418-1425.

37. Wang RJ (1976) Effect of room fluorescent light on the deterioration of tissue culture medium. In Vitro 12: 19-22.

38. Mahns A, Melchheier I, Suschek CV, Sies H, Klotz LO (2003) Irradiation of cells with ultraviolet-A (320-400 nm) in the presence of cell culture medium elicits biological effects due to extracellular generation of hydrogen peroxide. Free Radic Res 37: 391-397. 